\title{
Polysulfone-polyvinylpyrrolidone blend membranes as electrolytes in alkaline water electrolysis
}

Aili, David; Kraglund, Mikkel Rykær; Tavacoli, Joe; Chatzichristodoulou, Christodoulos; Jensen, Jens Oluf

Published in:

Journal of Membrane Science

Link to article, DOI:

10.1016/j.memsci.2019.117674

Publication date:

2020

Document Version

Peer reviewed version

Link back to DTU Orbit

Citation (APA):

Aili, D., Kraglund, M. R., Tavacoli, J., Chatzichristodoulou, C., \& Jensen, J. O. (2020). Polysulfone-

polyvinylpyrrolidone blend membranes as electrolytes in alkaline water electrolysis. Journal of Membrane Science, 598, [117674]. https://doi.org/10.1016/j.memsci.2019.117674

\section{General rights}

Copyright and moral rights for the publications made accessible in the public portal are retained by the authors and/or other copyright owners and it is a condition of accessing publications that users recognise and abide by the legal requirements associated with these rights.

- Users may download and print one copy of any publication from the public portal for the purpose of private study or research.

- You may not further distribute the material or use it for any profit-making activity or commercial gain

- You may freely distribute the URL identifying the publication in the public portal 


\title{
Polysulfone-polyvinylpyrrolidone blend membranes as
}

\section{electrolytes in alkaline water electrolysis}

\author{
David Aili*,=, Mikkel Rykær Kraglund", Joe Tavacoli, Christodoulos Chatzichristodoulou and \\ Jens Oluf Jensen \\ Department of Energy Conversion and Storage, Technical University of Denmark, Fysikvej, Building 310, \\ 2800 Lyngby, Denmark, "Corresponding author (E-mail: larda@dtu.dk); ${ }^{=}$These authors contributed equally to this \\ work
}

\begin{abstract}
Development of thin, dense and robust alkaline polymer membranes with high hydroxide ion conductivity is key to advanced alkaline electrolysis as it can enable operation at higher current density and/or efficiency, while improving the dynamic response of the electrolyzer. In this work, a homogeneous blend membrane system based on poly(arylene ether sulfone) (PSU) and poly(vinylpyrrolidone) (PVP) is explored as an alkaline ion-solvating polymer matrix. Increasing PVP content in the blend drastically increases electrolyte uptake, and at PVP contents higher than $45 \mathrm{wt} . \%$ the membrane can support ion conductivity in a technologically relevant range of 10-100 $\mathrm{mS} \mathrm{cm}-1$ or even higher when equilibrated in $20 \mathrm{wt} . \%$ aqueous $\mathrm{KOH}$. The membrane system is extensively characterized throughout the full composition range and the down-selected composition composed of $25 \%$ PSU and $75 \%$ PVP is employed in a single cell lab-scale water electrolyzer, showing excellent performance and stability during the course of one week at 500 $\mathrm{mA} \mathrm{cm}-2$ at $60{ }^{\circ} \mathrm{C}$ in $20 \mathrm{wt} . \% \mathrm{KOH}$. Good performance stability was demonstrated for more than
\end{abstract}


$700 \mathrm{~h}$ at $80^{\circ} \mathrm{C}$, but the gradually increasing $\mathrm{KOH}$ concentration due to evaporative loss of water resulted in membrane degradation.

Keywords: Alkaline membrane, polymer blend, support electrolyte, polysulfone, water electrolysis

\section{Introduction}

Water electrolysis provides a direct pathway for conversion of electrical energy to chemically bonded energy in the form of hydrogen, and is therefore emerging as one of the technological cornerstones in the renewable energy system [1]. Water electrolyzers constructed with alkaline electrolytes are robust and can be built entirely of abundant materials, but are notorious for being inefficient, having low rate capability and poor dynamic response capability [2]. The latter drawbacks have triggered extensive research and development of more efficient high rate electrolyzers with improved dynamic response characteristics based on proton exchange membranes (PEM) during the last decades, but their high cost and noble metal dependency are critical hurdles [3]. This implies that the scale of implementation is strictly limited by the availability of critical raw materials [4].

The most rational direction in the further development of energy- and cost efficient electrolyzers for large-scale applications is therefore to redesign the alkaline systems. One approach towards this target is to develop porous diaphragms that are thinner, yet exhibiting better gas-separation characteristic than the materials that are available on a commercial basis today [5]. This is a set of objectives that is difficult to achieve simultaneously without negatively impacting ionic conductivity. 
A more technologically sophisticated solution is cells based on anion exchange membranes (AEM), which ideally makes it possible to operate the cell with pure water feed [6-10]. However, a dilute alkaline supporting electrolyte is often used as it greatly improves the cell performance [11-14]. This is indeed a promising approach, but the intrinsic instability of the cationic head groups in the hydroxide form is a formidable challenge in the development of stable AEMs [15].

A third option is to employ a polymer membrane that is imbibed with an aqueous alkaline electrolyte. This approach combines the mechanical robustness and gas separation characteristics of the structural base polymer with the conductive properties of the imbibed aqueous alkaline salt solution [16]. Membranes based on polybenzimidazoles are particularly interesting in this connection as they are mechanically robust and can support ion conductivities as high as $0.1 \mathrm{~S}$ $\mathrm{cm}^{-1}$ in aqueous $\mathrm{KOH}$ with concentrations around 20-25 wt.\% [17-19]. The concept has been intensively developed during the last few years [20-24], and we have now reached a stage where performances comparable to the state-of-the-art PEM systems can be obtained with a cell and electrode design that is completely free from noble metals [25].

The polybenzimidazole membranes show excellent stability in aqueous $\mathrm{KOH}$ in the lower concentration range, but degradation becomes apparent when the concentration is increased [26] and the membrane degradation is further accelerated during cell operation [21]. It is well-known that the covalent bond between the (benz)imidazole and phenylene moieties in (benz)imidazole derived polymers is a weak link in alkaline environment [27, 28]. Although steric protection of this position [12, 29-31] or introduction of electron rich heteroatoms in the polymer backbone [32] have proven effective strategies for mitigating the degradation, complete alleviation of the degradation in (benz)imidazole derived polymers remains a challenge. 
The poly(arylene ether sulfones) comprise a large family of polymers and many derivatives in this group of materials combine excellent alkali resistance with good processing characteristics. As such, they are used as polymeric binders in the modern porous diaphragms for alkaline water electrolysis $[33,34]$. Chemical modifications of the polymer backbone is relatively straightforward and a large number of quaternary ammonium functionalized poly(arylene ether sulfones) have been reported as AEMs for e.g. alkaline fuel cells [35]. However, the grafting of side chains with cationic head groups seems to trigger backbone degradation of the polymer [36]. This is likely due to a combination of the enhanced alkali uptake, which makes the vulnerable aryl ether bonds more exposed to the hydroxide ions, and the electron deficiency of the cationic sites, which results in electron redistribution and enhanced electrophilicity of the weakest links [37].

An alternative strategy to promote water or electrolyte uptake of membranes based on poly(arylene ether sulfone) derivatives is to blend the polymer with a secondary highly hydrophilic polymer, e.g. poly(vinylpyrrolidone) (PVP). This concept has been used for the preparation of membranes for dialysis for many years $[38,39]$ and was recently investigated for high temperature polymer electrolyte membrane fuel cells [40-42] and redox flow batteries [43, 44]. In the context of alkaline water electrolysis, PVP has previously been used as hydrophilic additive to poly(arylene ether sulfone) for the preparation of porous diaphragms by phase inversion casting [45]. Furthermore, polymer blend membranes of PVP and poly(ether sulfone) (PES) at relatively low PVP contents have been assessed with respect to electrolyte uptake, ion conductivity and cell performance in alkaline electrolyzers [46].

This work presents a systematic study of blend membranes composed of poly(arylene ether sulfone) (Udel ${ }^{\circledR}$ polysulfone, PSU) and PVP prepared by co-casting and covering the entire composition range. It was found that the aqueous $\mathrm{KOH}$ uptake was promoted by PVP, particularly 
at PVP contents higher than $45 \mathrm{wt} . \%$. Even at PVP contents as high as $60-90 \mathrm{wt} . \%$, mechanically robust membranes with ion conductivity in a technologically relevant range of $27-167 \mathrm{mS} \mathrm{cm}^{-1}$ in 20 wt. $\%$ aqueous $\mathrm{KOH}$ was reached at room temperature. The blend membrane containing $75 \%$ PVP was down-selected for further electrolysis testing with respect to cell performance and stability during the course of one week at $500 \mathrm{~mA} \mathrm{~cm}^{-2}$ at $60{ }^{\circ} \mathrm{C}$ in $20 \mathrm{wt} . \% \mathrm{KOH}$.

\section{Experimental}

\subsection{Materials}

Polysulfone (PSU, Udel ${ }^{\circledR}$ P-3500-NT-LCD) was supplied by Solvay and poly(vinylpyrrolidone) (PVP, K15) from Aldrich. $N, N$-dimethylacetamide (DMAc) and potassium hydroxide pellets (assay $\geq 85 \% \mathrm{KOH}, \leq 1 \% \mathrm{~K}_{2} \mathrm{CO}_{3}$ ) were from Sigma Aldrich. Density measurements were carried out to determine the concentrations by comparison with data in the literature [47]. Zirfon Perl UTP 500 was supplied by Agfa and the polybenzimidazole (poly(2,2'-( $m$-phenylene)-5,5'bibenzimidazole), $m$-PBI) membrane was prepared as reported elsewhere [48]. For electrode preparation, nickel foam (mean pore size/thickness: $800 / 2500 \mu \mathrm{m}$ and 450/1600 $\mu \mathrm{m}$ ) supplied by Alantum was used. $\mathrm{Ni}\left(\mathrm{NO}_{3}\right)_{2} \cdot 6 \mathrm{H}_{2} \mathrm{O}$ (purity 99.985\%), $\left(\mathrm{NH}_{4}\right)_{6} \mathrm{Mo}_{7} \mathrm{O}_{24} \cdot 4 \mathrm{H}_{2} \mathrm{O}(99 \%)$ and Urea $(98+\%)$ were supplied by Alfa Aesar while $\mathrm{Fe}\left(\mathrm{NO}_{3}\right)_{3} \cdot 9 \mathrm{H}_{2} \mathrm{O}(98 \%)$ was supplied by Sigma Aldrich.

\subsection{Membrane preparation}

The membrane casting solutions were prepared by co-dissolving PSU and PVP in DMAc by vigorous stirring at room temperature, to give polymer blends with PVP contents ranging from 0 90 wt.\%. The PSU solid content was kept at 3.3 wt.\% with respect to DMAc and the amount of PSU was kept constant ( $0.3 \mathrm{~g})$ for all casting solutions, which implies that the composition of the 
membranes was controlled by changing the amount of PVP added. The membranes were cast on Petri dishes with a diameter of $10.8 \mathrm{~cm}$ on levelled glass plates mounted in a Memmert UN 55 Plus oven, by gradually raising the temperature to $120^{\circ} \mathrm{C}$ over two days. The Petri dishes were partially covered during casting to maintain a high solvent partial pressure above the surface of the casting solution. Transparent and visually homogenous polymer blend membranes were obtained, which were delaminated in demineralized water and treated in demineralized water at 60 ${ }^{\circ} \mathrm{C}$ for $2 \mathrm{~h}$. The membranes were stored in demineralized water until used. Doping with aqueous $\mathrm{KOH}$ was carried out by equilibrating the membranes in 10 or $20 \mathrm{wt} . \%$ aqueous $\mathrm{KOH}$ at room temperature for at least $16 \mathrm{~h}$.

\subsection{Electrode preparation}

Electrodes were prepared following common procedures previously described in literature modified for the current study $[49,50]$. The NiFe layered double hydroxide (LDH) anodes were prepared by a hydrothermal method. Nickel foam pieces $\left(3.6 \times 4.0 \mathrm{~cm}^{2}, 800 / 2500 \mu \mathrm{m}\right)$ were immersed into $80 \mathrm{~mL}$ aqueous solution containing metal nitrates (nickel:iron 1:1, total $6.25 \mathrm{mM}$ ) and urea $(62.5 \mathrm{mM})$ in a $100 \mathrm{~mL}$ PTFE lined autoclave, then kept at $120{ }^{\circ} \mathrm{C}$ for $12 \mathrm{~h}$. Similarly, the $\mathrm{MoNi}_{4}$ cathodes were prepared by immersing the nickel foams in $80 \mathrm{~mL}$ aqueous nickel nitrate $(40 \mathrm{mM})$ and ammonium molybdate $(10 \mathrm{mM})$ at $150{ }^{\circ} \mathrm{C}$ for $6 \mathrm{~h}$ in a $100 \mathrm{~mL}$ PTFE lined autoclave. The formed cathodes were then reduced $\left(5 \% \mathrm{H}_{2}\right.$ in $\left.\mathrm{Ar}\right)$ at $500{ }^{\circ} \mathrm{C}$ for $30 \mathrm{~min}$.

\subsection{Characterization}


The water content of the membranes after the work-up procedure in demineralized water at $60^{\circ} \mathrm{C}$ for $2 \mathrm{~h}$ was determined on the total wet membrane mass basis by recording the mass before $\left(m_{w e t}\right)$ and after $\left(m_{d r y}\right)$ drying at $110^{\circ} \mathrm{C}$, according to Equation 1 .

Water content $=\left(\left(m_{w e t}-m_{d r y}\right) / m_{w e t}\right) \times 100 \%$

The volumetric change following the drying process in the water content determination was calculated according to Equation 2, where $t_{w e t}$ and $t_{d r y}$ is the thickness (taken as the average of 5 points) of the wet and dry membranes, respectively, and $d_{w e t}$ and $d_{d r y}$ is the diameter of the wet and dry membranes, respectively.

Volume change $=\left(\left(t_{d r y} \times \pi \times\left(d_{d r y} / 2\right)^{2}\right)-\left(t_{\text {wet }} \times \pi \times\left(d_{\text {wet }} / 2\right)^{2}\right)\right) /\left(t_{\text {wet }} \times \pi \times\left(d_{w e t} / 2\right)^{2}\right) \times 100 \%$

Round samples, with a diameter of $32 \mathrm{~mm}$ in the wet state, were used for the water content and volumetric change determination and prepared by die cutting. A series of membranes with one sample of each composition was measured.

The membrane composition after equilibration in aqueous $\mathrm{KOH}$ at room temperature for at least $16 \mathrm{~h}$ was determined gravimetrically using an analytical balance by calculating the weight fractions of polymer (PSU and PVP) $\left(X_{\text {polymer }}\right), \mathrm{KOH}\left(X_{\mathrm{KOH}}\right)$ and water $\left(X_{\text {water }}\right)$ as shown in Equations 3-5. Here, $m_{\text {doped }}$ is the mass of the membrane after equilibration in aqueous $\mathrm{KOH}$ after careful blotting with tissue paper, $m_{d r y}$ is the mass of the membrane after drying at $110^{\circ} \mathrm{C}$ for $2 \mathrm{~h}$ and $m_{\text {dedoped }}$ is the mass of the polymer fraction (PSU + PVP) of the membrane after extensive washing in demineralized water until neutral $\mathrm{pH}$ followed by drying at $110^{\circ} \mathrm{C}$ for $4 \mathrm{~h}$. A series of 
membranes with one sample of each composition was measured. Eventual remaining traces of water and $\mathrm{KOH}$ in the dried and dedoped samples would lead to a slight underestimation of the corresponding mass fractions of the membranes.

$X_{\text {polymer }}=\left(m_{\text {dedoped }} / m_{\text {doped }}\right) \times 100 \%$

$X_{K O H}=\left(\left(m_{\text {dry }}-m_{\text {dedoped }}\right) / m_{\text {doped }}\right) \times 100 \%$

$X_{\text {water }}=\left(\left(m_{\text {doped }}-m_{\text {dry }}\right) / m_{\text {doped }}\right) \times 100 \%$

The chemical stability of the membranes was assessed by aging the membranes in $20 \mathrm{wt} . \% \mathrm{KOH}$ at $60{ }^{\circ} \mathrm{C}$ for one week in sealed polypropylene bottles.

Scanning electron microscopy (SEM) imaging (backscattered) was carried out on the membrane surfaces (sputter coated with carbon) using a Carl Zeiss EVO MA10. The Fourier transform infrared (FTIR) spectra were recorded using a Perkin Elmer Spectrum Two equipped with a universal attenuated total reflectance (ATR) accessory. The ${ }^{1} \mathrm{H}$ nuclear magnetic resonance $\left({ }^{1} \mathrm{H}\right.$ NMR) spectra were recorded on a Bruker Ascend operating at $400 \mathrm{MHz}$. Deuterated chloroform $\left(\mathrm{CDCl}_{3}\right)$ was used as solvent and the chemical shifts are given relative to the solvent residual signal at $7.26 \mathrm{ppm}$. The thermogravimetric data were acquired using a Netsch STA 409 PC under air and using a linear heating gradient of $5{ }^{\circ} \mathrm{C} \mathrm{min}^{-1}$. Tensile tests were carried out using a Testometric Micro 350 universal materials testing machine at a crosshead speed of $10.00 \mathrm{~mm}$ $\mathrm{min}^{-1}$, using dog-bone shaped specimens ( $2 \mathrm{~mm}$ wide and $28 \mathrm{~mm}$ between the shoulders). At least 4 specimens of each membrane type were prepared by die-cutting using a hydraulic press and 
stored in demineralized water until they were mounted for testing. The mounting and testing was carried out rapidly under ambient atmosphere (during approximately 5 minutes), to minimize loss of water from the samples during the measurement.

The ion conductivity was measured at room temperature in tubular conductivity cell made of two separate PTFE blocks. Electrodes made of nickel mesh with point-welded electrical connections were fixed in each block using PTFE gaskets. The cell diameter was $0.9 \mathrm{~cm}$ and when assembled, the interelectrode distance was $2.0 \mathrm{~mm}$. The cell was filled with electrolyte through holes in each block, and purged with electrolyte using a syringe to remove trapped air. The resistance between the electrodes was recorded at room temperature by electrochemical impedance spectroscopy (EIS) using a VersaStat 3 from Princeton Applied Research at $10 \mathrm{mV}$ amplitude and in the frequency range $10^{2}-10^{6} \mathrm{~Hz}$ and taken as $Z_{r e}$ at $Z_{\text {im }}=0 \Omega$. The ion conductivity $\sigma$ of the membranes was calculated according to Equation 6, where $t$ is the thickness of the membrane, $R$ is the resistance with the membrane mounted between the electrodes, $R_{\text {blank }}$ is the resistance of the electrolyte filling the gap between the membrane and the electrodes (1.0 mm on each side) and $A$ is the cross-sectional area of the cell.

$\sigma=t /\left(\left(R-R_{\text {blank }}\right) \times A\right)$

\subsection{Electrolysis tests}

Single cell alkaline water electrolysis tests were done in a $11.6 \mathrm{~cm}^{2}$ flow cell. The cell house was made from steel and coated with electroless nickel. The cell house employed a pin-type flowfield. Prior to cell assembly, the prepared electrodes were die cut to circular $11.6 \mathrm{~cm}^{2} \operatorname{discs}(\emptyset 38.5 \mathrm{~mm})$, pressed with spacers to a thickness of $470-500 \mu \mathrm{m}$ (to reduce the likelihood of membrane 
puncture), and sonicated in water for 5 minutes. $11.6 \mathrm{~cm}^{2}$ was used as the active area for current normalization. The electrolysis tests were carried out using the membranes composition with an initial PVP content of $75 \mathrm{wt} . \%$ (cast to different thicknesses), which were pre-doped overnight in $20 \mathrm{wt} \% \mathrm{KOH}$ at room temperature before the electrolysis tests. The membranes were thereafter cut to fit the cell and assembled together with the cell house, electrodes, and PTFE and EPDM gaskets, in horizontal position by carefully alignment of components. The cell was mounted in a test setup built primarily from PFA and PTFE. Heating and temperature probing was done directly in the cell house. For electrolyte, $400 \mathrm{~mL}$ of $20 \mathrm{wt} . \% \mathrm{KOH}$ solution was circulated by PSU/Hastelloy gear pumps at $70 \mathrm{~mL} \mathrm{~min}^{-1}$ in partially separated electrolyte circuits [51]. The generated gasses were vented from $500 \mathrm{~mL}$ PTFE bottles used as electrolyte reservoirs by loosely mounting the bottle caps to condensate vapors but enable gas dissipation.

Initial cells tests were done with the prepared NiMo cathodes and $\mathrm{NiFe}$ anodes and were conducted according to the following protocol: After reaching a stable temperature at $60{ }^{\circ} \mathrm{C}, 100$ $\mathrm{mA} \mathrm{cm}{ }^{-2}$ was applied for 30 minutes. This was followed by EIS measurements and a polarization curve, after which the cell was left at $500 \mathrm{~mA} \mathrm{~cm}^{-2}$. After almost one week another set of EIS measurements were recorded followed by a final polarization curve. A secondary cell test was operated at $80{ }^{\circ} \mathrm{C}$ with a proprietary cathode and a pressed plain nickel foam anode (450/1600 $\mu \mathrm{m})$. The cell was initiated at $100 \mathrm{~mA} \mathrm{~cm}^{-2}$ for 30 min after which the initial polarization curve was recorded. The cell was left at $500 \mathrm{~mA} \mathrm{~cm}^{-2}$ for $>700 \mathrm{~h}$, with polarization curves being recorded every week. Water was added regularly on basis of the faradaic consumption of water. Polarization curves were recorded stepwise galvanostatically with a residence time of 2 minutes per setpoint. Data shown represent an average over the last minute at each setpoint. Power was supplied by an Elektro Automatik EA-PS-5040-40 A power supply, and controlled through a LabVIEW interface. 
EIS were done by briefly stopping the cell and temporarily switching cables to a VersaStat 4, and recorded galvanostatically at 10 and $100 \mathrm{~mA} \mathrm{~cm}^{-2}$, over the frequency range $100,000-0.05 \mathrm{~Hz}$ with an amplitude corresponding to $10 \%$ of the setpoint. Data were fitted with a L-R-RQ-RQ equivalent circuit model.

\section{Results and discussion}

\subsection{Membrane preparation}

Homogeneous membrane casting solutions were obtained by co-dissolving PSU and PVP in DMAc during stirring at room temperature, and membranes with PVP contents ranging from 0-90 wt. \% were cast by solvent evaporation by heating from room temperature to $120^{\circ} \mathrm{C}$. The chemical structures of the membrane constituents and the membrane formation processes are illustrated in Figure 1. Visually homogeneous and transparent membranes were obtained throughout the whole composition range and the membranes with PVP contents higher than $45 \mathrm{wt} . \%$ appeared slightly yellowish. The transparency and visual homogeneity of the obtained membranes indicate that the polymers are fully miscible in the whole composition range, which seems supported by differential scanning calorimetry studies on blends of PVP with PSU [42] or a structurally similar polysulfone derivative (poly(ether sulfone), PES) [40, 46]. 

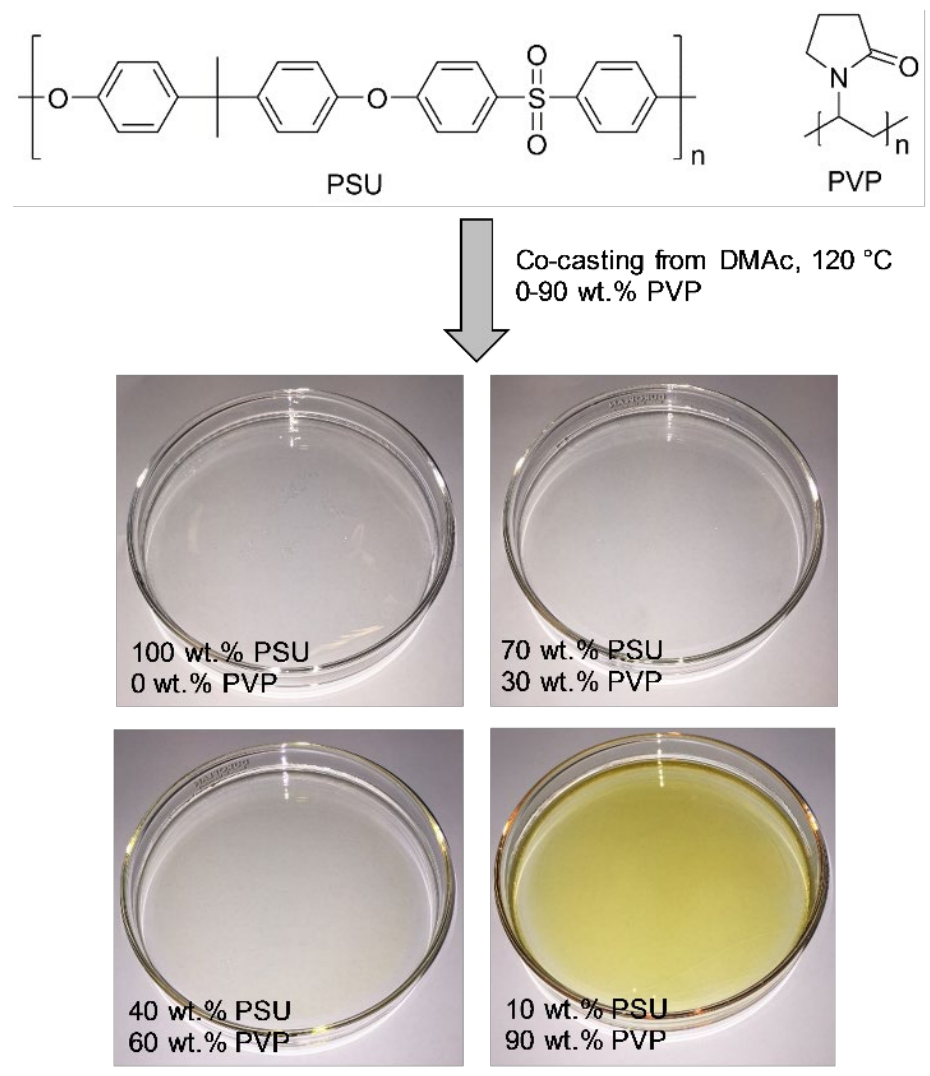

Figure 1 Chemical structure of PSU and PVP and photographs of the membranes after casting.

After casting, the membranes were delaminated from the glass substrates in water and further treated in demineralized water at $60{ }^{\circ} \mathrm{C}$ for several hours. As seen from the SEM micrographs of the membrane surfaces in Figure S1, the water treatment did not result in any apparent formation of pores on the micrometer scale. Even on the nanometer scale, transmission electron microscopy imaging carried out by Lu et al. [46] on a poly(ether sulfone) blend with PVP showed no signs of porosity after treatment in alkaline ethanol. Hayama et al. [38] used atomic force microscopy (AFM) to image surfaces of the PSU-PVP blend system on the nanometer length scale. It was revealed that nanometer sized agglomerates were formed on the membrane surfaces and the size of the agglomerates tended to decrease with decreasing PVP molecular weight. At PVP molecular weights comparable to that of the PVP used in the present work, the size of the PVP agglomerates 
was estimated to around $10 \mathrm{~nm}$. As this is similar to or slightly larger than the calculated Stokes diameter of the polymer, one can conclude that the PVP agglomerates are composed of one single to a few polymer chains [38]. This seems further supported by the small angle X-ray scattering data reported by $\mathrm{Wu}$ et al. [52], which show the dimensions of the polymer agglomerates is around $15 \mathrm{~nm}$. On even smaller length scales, X-ray diffraction data show that the polymer blends are amorphous throughout the entire composition range [53].

Since PVP is a highly hydrophilic polymer that is soluble in water one might expect that the PVP is washed out from the membrane during work-up in hot water. However, as shown in Figure 2a, the FT-IR spectra of the dry membrane surfaces after treatment in water showed the characteristic PVP carbonyl absorption at around 1600-1700 $\mathrm{cm}^{-1}$. Pure PVP shows a peak maximum at around $1650 \mathrm{~cm}^{-1}$, as also clearly observed in the spectra of the membranes with an initial PVP content of 60, 75 and 90 wt.\%. At PVP contents lower than 45 wt.\% the peak maximum shifted to around $1680 \mathrm{~cm}^{-1}$, which indicates a change in the chemical environment of the carbonyl group of PVP. This suggests that the carbonyl groups of PVP are involved in the interactions with PSU. The interactions were apparently non-covalent, since the membranes readily dissolved in organic solvents (e.g. chloroform). At higher PVP contents of 60-90 wt.\%, the carbonyl signal is dominated by the excess PVP that is not interacting with PSU, resulting in a carbonyl signal with an identical peak maximum as pure PVP. The area under the PVP absorption band area relative to the characteristic PSU peaks (e.g. at 1580,1230 or $560 \mathrm{~cm}^{-1}$ ) increased as the PVP content increased, supporting that major fraction of PVP remained in the membrane after work-up.

The ${ }^{1} \mathrm{H}$ NMR spectra of the polymer blend membranes after work-up in water and drying are shown in Figure $2 b$, and confirm the presence of both polymers. Pure PSU showed well- 
resolved peaks with a coupling pattern and integrals perfectly matching its chemical structure. The spectrum of pure PVP appeared as a series of multiplets at 1.5-4 ppm.

The peak integral ratios of the PSU and PVP signals were used to calculate the PVP content in the polymer blends after the work-up in water, and the results are summarized in Figure $2 \mathrm{c}$ by the black markers. The calculation was based on the relative peak integrals of the signals at 7.85 ppm for PSU (4H) and the broad multiplet of PVP at 1-4 ppm (which was corrected for the contribution from the PSU methyl signal at $1.70 \mathrm{ppm}$ ). The discussion about the composition after aging in $\mathrm{KOH}$ will follow in section 3.2. The PVP content determined for the membranes prepared from the blends with PVP contents of 0-45 wt.\% was in good agreement with the nominal initial composition of the blend. For example, the PVP content of the membranes prepared from the polymer blends containing 15, 30 and $45 \mathrm{wt} . \%$ was determined to 17,23 and $42 \mathrm{wt} . \%$ after workup in water, respectively. As suggested by the FT-IR spectra, it represents the composition range where there is little excess PVP that is not bound through interactions with PSU. At high initial PVP contents, i.e. 60-90 wt.\%, larger discrepancies between the initial nominal PVP content in the casting solution and the PVP contents determined by ${ }^{1} \mathrm{H}$ NMR after work-up were observed. This further supports the FT-IR data, which suggested that excess PVP was present in the membranes that was not immobilized by interactions with PSU. After work-up in water, the PVP content of the membrane prepared from a polymer blend containing $90 \mathrm{wt} . \%$ PVP was determined to 73 wt.\%. The data indicate that partial wash-out of PVP occurred during work-up for the membranes with initial PVP contents in the higher end of the composition range. It should be remarked that the total PSU loading in the membrane was kept constant and thus the total membrane thickness increased with increasing PVP content, which is another parameter that could influence the leaching behavior of the water-soluble component. 

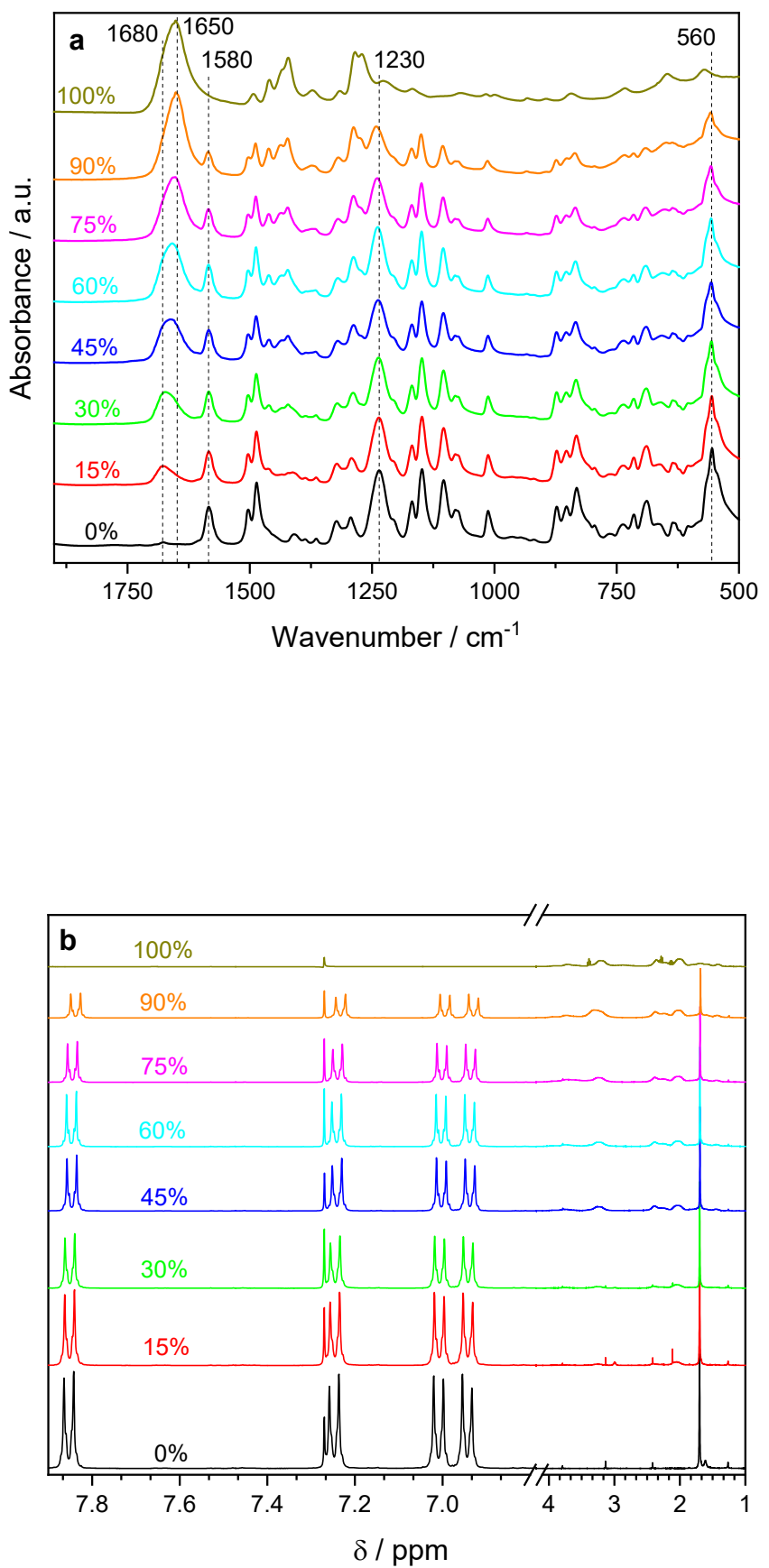


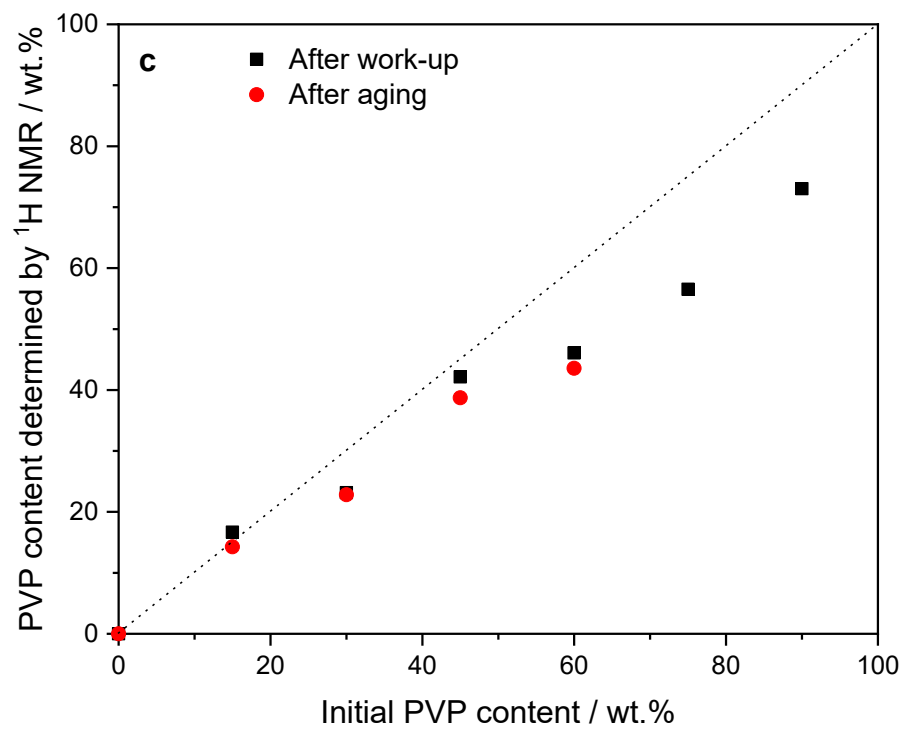

Figure 2 FT-IR (a), ${ }^{1} \mathrm{H}$ NMR (b) and PVP contents determined from the ${ }^{1} \mathrm{H}$ NMR peak integrals (c) of the dried polymer blends with an initial PVP content of 15-90 wt.\%. Spectra for pure PSU $(0 \%)$ and PVP (100\%) are shown for comparison in (a) and (b). The dotted line in (c) is included as guide for the eye and the PVP contents after aging in $20 \mathrm{wt} . \%$ aqueous $\mathrm{KOH}$ for one week at $60{ }^{\circ} \mathrm{C}$ are shown for comparison.

As shown by the thermogravimetric curves in Figure 3, pure PSU showed negligible weight loss at temperatures up to around $400{ }^{\circ} \mathrm{C}$. PVP, on the other hand, showed an initial weight loss around $100{ }^{\circ} \mathrm{C}$, likely corresponding to the evaporation of water. An onset temperature of decomposition was observed at $132{ }^{\circ} \mathrm{C}$, followed by gradual weight loss until a major onset of decomposition was reached at about $390{ }^{\circ} \mathrm{C}$. Apart from the water evaporation at around $100{ }^{\circ} \mathrm{C}$, the membranes based on the polymer blends showed no apparent weight loss at temperatures up to $300{ }^{\circ} \mathrm{C}$. Even a small fraction of PSU in the blend (90\% PVP) resulted in a significant improvement of the thermal stability as compared with pure PVP. It indicates significant intermolecular forces between the 
polymers, which ultimately result in stabilization of PVP as discussed in the previous paragraphs in connection to Figure $2 \mathrm{a}$ and $2 \mathrm{c}$.

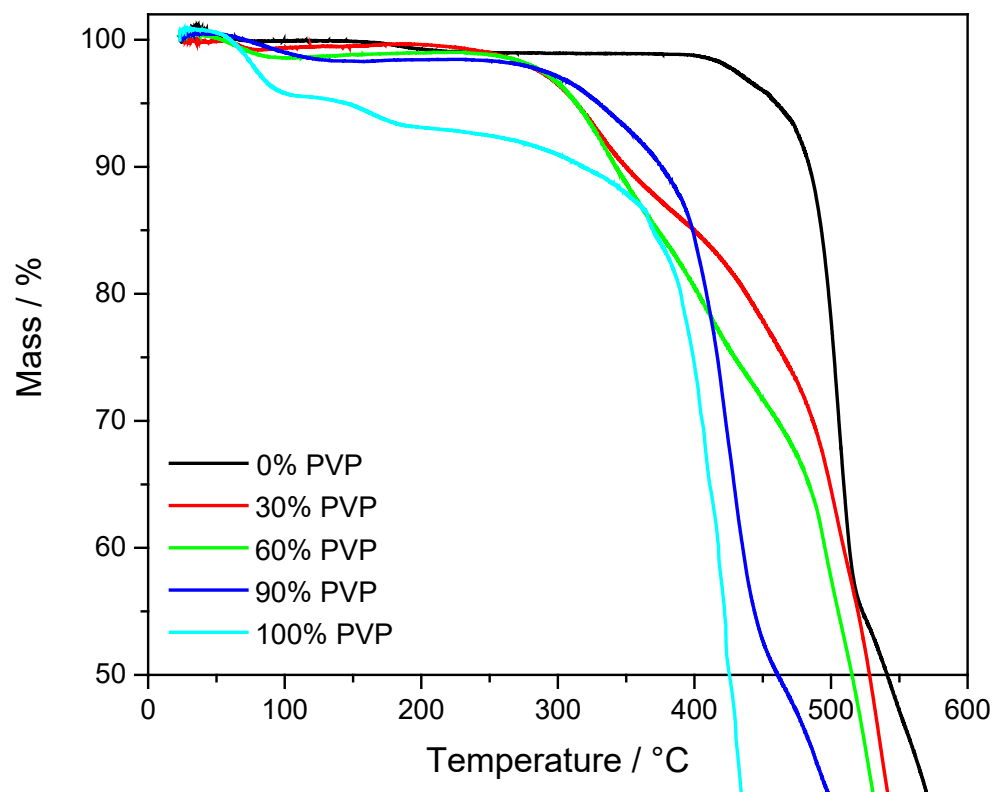

Figure 3 Thermogravimetric curves of the dry membranes (after work-up in water) prepared from the polymer blends containing 30, 60 and $90 \mathrm{wt} . \%$ PVP. The data for pure PSU and PVP are shown for comparison. The measurements were carried out under air at a linear heating gradient of $5{ }^{\circ} \mathrm{C} \mathrm{min}^{-1}$.

To avoid eventual irreversible changes in the membrane hydration characteristics, the water content and corresponding volume changes (instead of water uptake and swelling) were determined from the weight and volume changes upon drying, as shown in Figure 4. As previously reported [44], the water mass fraction of the membrane increased with increasing PVP content of the membranes, and reached 9,34 and $61 \%$ of the total wet membrane mass for the membranes with a PVP content of 30, 60 and 90 wt.\% in the initial polymer blend, respectively. At PVP contents below $45 \mathrm{wt} . \%$, the water evaporation was accompanied by minor volume reductions. 
This suggests that water was mainly absorbed into the free volume of the polymer blend. The membranes with PVP contents higher than 45 wt.\% were brittle after drying, which complicated the volume determination in the dry state. However, it is evident that the drying of the membranes with PVP contents higher than 45 wt.\% was accompanied by significant volume reductions. The water uptake and swelling behavior of the membranes indicate that the cohesive intramolecular PSU interactions that prevent the pure polymer from swelling in water are weakened at PVP contents above 45 wt.\%. Instead, the membrane characteristics are dominated by the highly hydrophilic PVP component, which supports further water uptake and volume swelling. Ultimately, excessive water uptake and swelling would enhance the leaching of PVP from the polymer blend system, which was also confirmed by the quantification using NMR and discussed above. The leaching of PVP seemed more pronounced in the higher end of the composition range, which would leave more free volume for water and thus a more significant volume change during drying. 


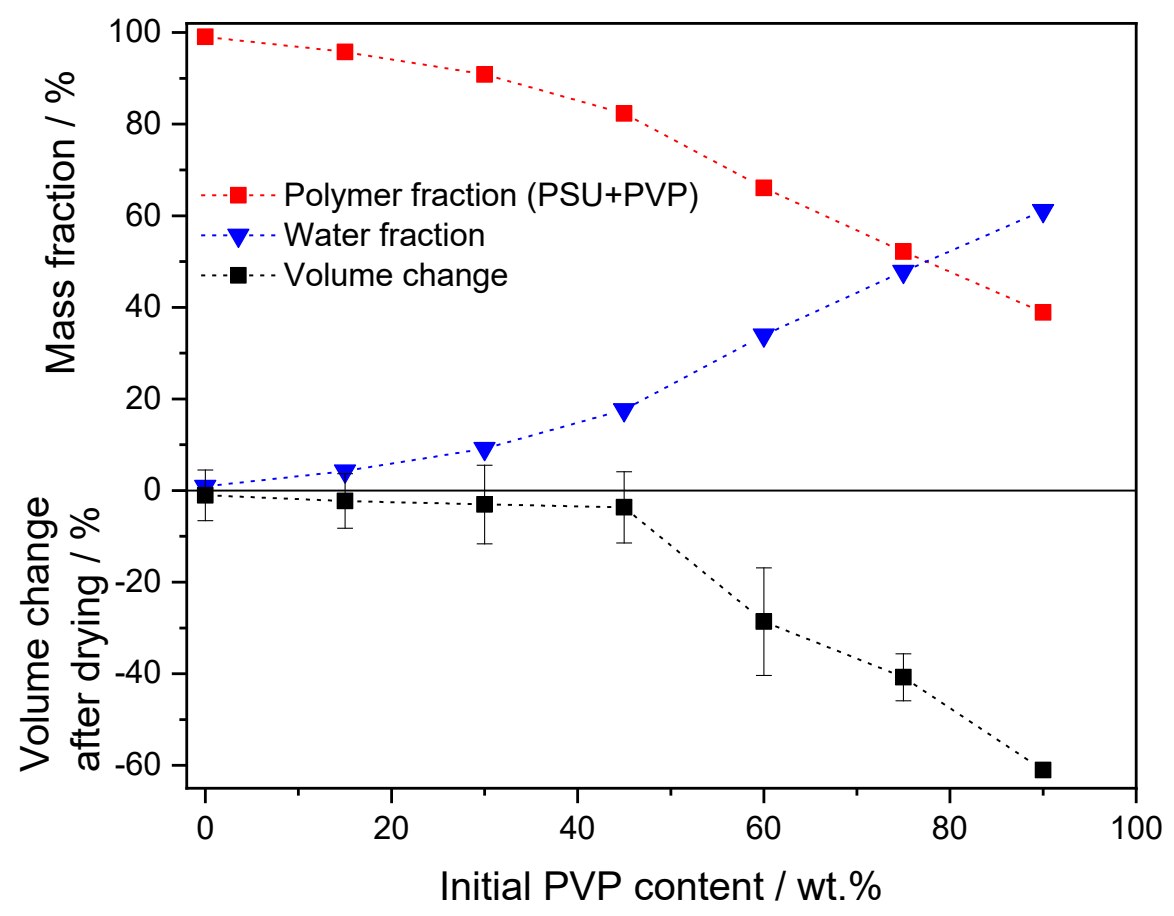

Figure 4 Membrane composition after equilibration in water (top) and volume change after drying (bottom). The standard deviation as indicated by the error bars was calculated based on repeated thickness and diameter measurements on the same sample.

As shown in Figure 5a, the water-saturated membranes showed decreasing tensile strength and increased elongation at break as the PVP content of the polymer blend increased. The gradual change in tensile behavior as the composition of the membrane changes is largely connected to the differences in water content, as water is well known to exert a strong plasticizing effect in other polymer electrolyte systems based on e.g. perfluorosulfonic acid [54] or polybenzimidazole membranes [55]. At PVP contents higher than 45 wt.\%, i.e. where the intermolecular PSU interactions that work against further swelling are weakened by PVP, the yield point was dramatically reduced. For example, as summarized in Figure 5b, the pure PSU membrane showed 
a yield point of $75 \mathrm{MPa}$, which can be compared with $3 \mathrm{MPa}$ for the membrane with a PVP content of 75 wt.\%. While the pure PSU membrane showed an elastic modulus of nearly $2900 \mathrm{MPa}$, the elastic modulus of the membranes with PVP contents of 60 and 75 wt.\% was 417 and $130 \mathrm{MPa}$, respectively. The membrane containing 90\% PVP suffered from extreme plasticization due to the high water uptake, and showed very limited elastic deformation in contrast to the membranes with lower PVP contents. The elastic modulus of the membrane containing $90 \mathrm{wt} . \%$ PVP was as low as $9 \mathrm{MPa}$ and the corresponding yield strength was nearly negligible, clearly showing that the tensile behavior was dominated by plastic deformation. For comparison, the elastic modulus of a fully hydrated polybenzimidazole membrane is similar to that of the pure PSU membrane but drops to about $390 \mathrm{MPa}$ after equilibration in $25 \mathrm{wt} \% \%$ aqueous $\mathrm{KOH}$ [26].

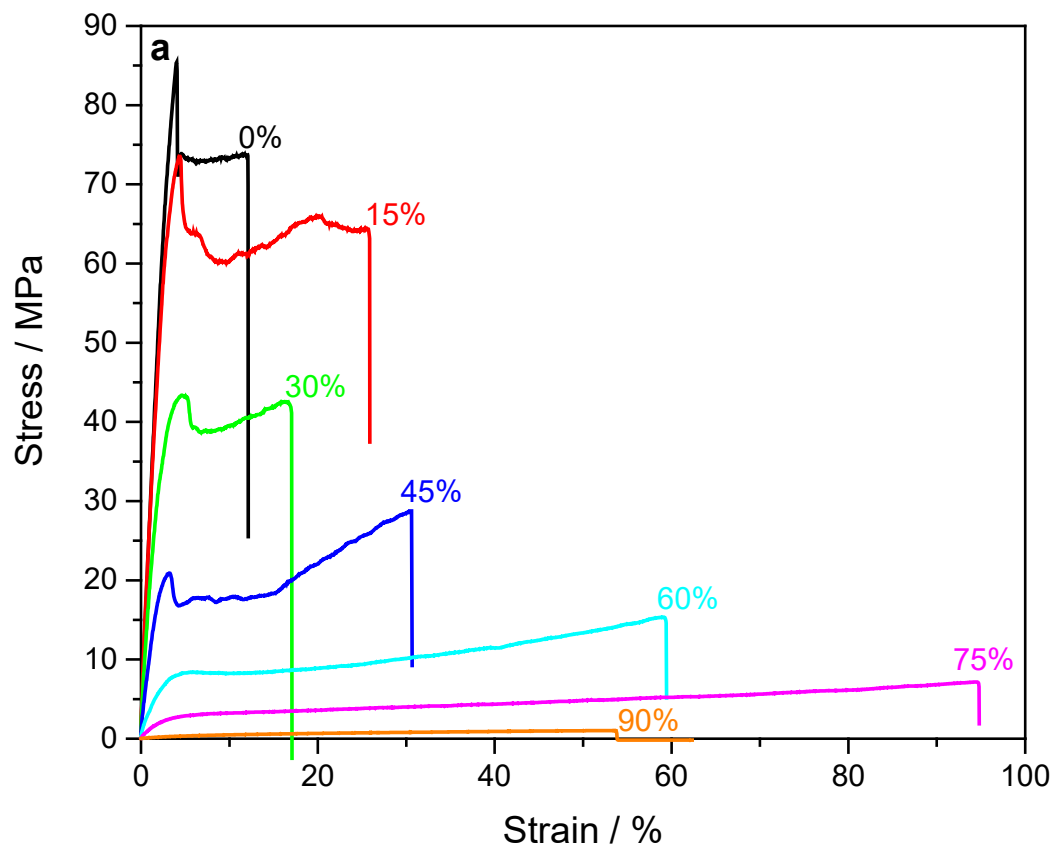




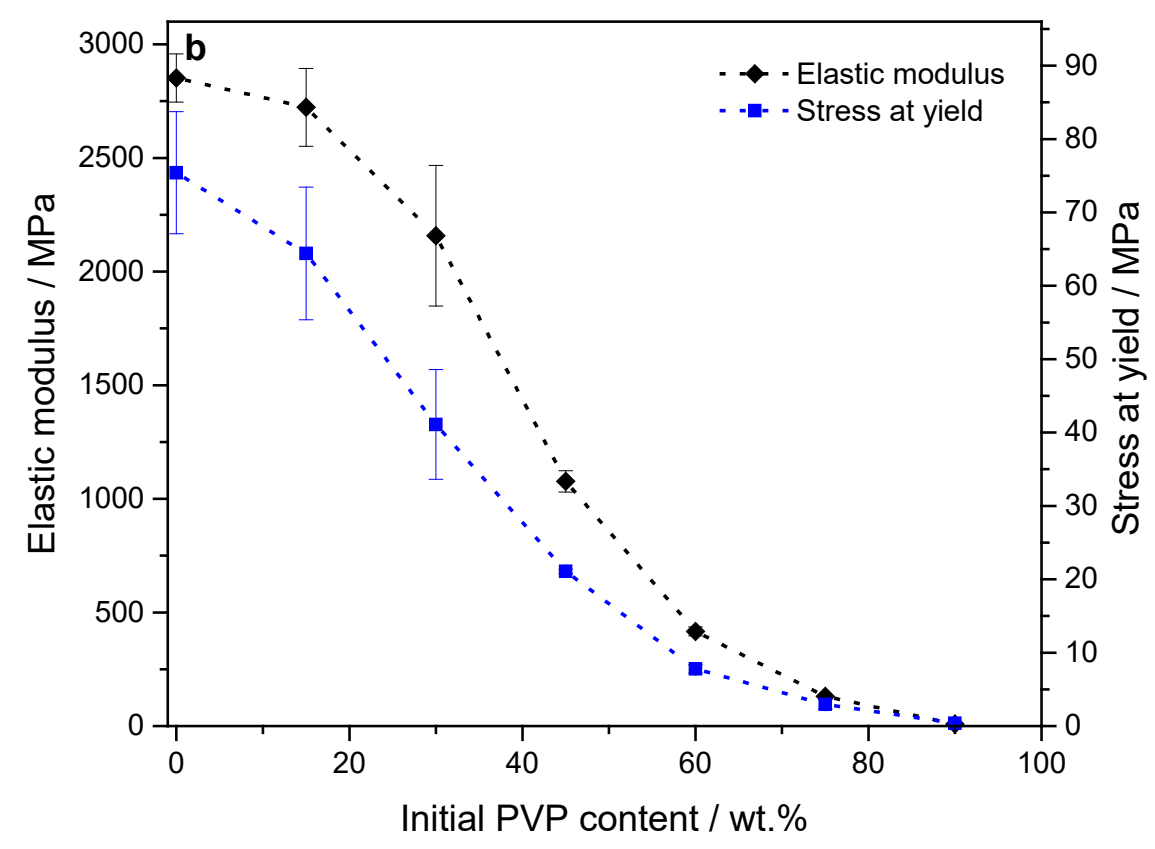

Figure 5 Representative stress-strain curves (a) and elastic modulus (b) of the membranes prepared from the polymer blends containing 0-90 wt.\% PVP.

\subsection{Doping with aqueous KOH}

Since the blend membranes are not containing any ionizable groups that can dissociate in the presence of water, further equilibration in an aqueous electrolyte is needed in order to obtain a membrane that can support ion conductivity. The membranes were therefore treated in aqueous $\mathrm{KOH}$ at room temperature for at least $16 \mathrm{~h}$ in order to replace the water within the membrane structure with aqueous electrolyte. The composition of the membranes with initial PVP contents of 0-90 wt.\% after equilibration in 10 or 20 wt.\% are shown in Figure 6. As shown in Figure 2c, partial crosslinking or wash-out of PVP may occur during the equilibration in aqueous $\mathrm{KOH}$ and the polymer fractions of the membranes are therefore given as the total polymer fractions (PSU + PVP). The leaching of PVP was most significant at initial PVP contents higher than $45 \mathrm{wt} . \%$. In analogy with the water uptake data, the electrolyte content of the membrane increased with 
increasing PVP content of the membrane and particularly at PVP contents higher than 45 wt.\%. At a PVP content of $75 \mathrm{wt} . \%$, the aqueous electrolyte dissolved within the membrane structure constituted about half of the membrane mass. This is similar to the electrolyte uptake of polybenzimidazole membranes equilibrated in 20-25 wt.\% aqueous $\mathrm{KOH}$ [18]. At 90 wt.\% PVP content in the polymer blend, the membrane was composed of nearly $70 \mathrm{wt} . \%$ aqueous electrolyte, yet with sufficient mechanical robustness for handling and processing.

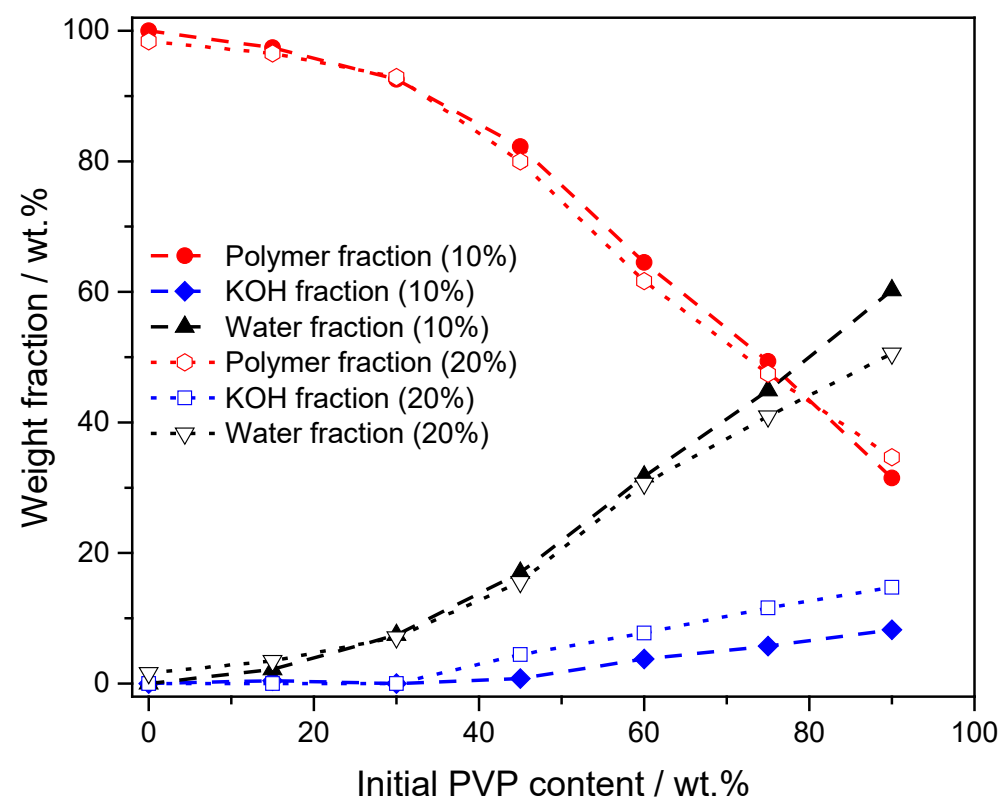

Figure 6 Composition of the membranes prepared from the polymer blends containing 0-90 wt.\% PVP after equilibration in aqueous $\mathrm{KOH}$ with concentrations of $10 \mathrm{wt} . \%$ (solid symbols) and 20 wt.\% (open symbols).

The ion conductivity of the membranes prepared from polymer blends with PVP contents of 3090 wt. $\%$ was recorded in 10 or 20 wt. $\% \mathrm{KOH}$ at room temperature after equilibrating the membranes at same concentration for $16 \mathrm{~h}$. In contrast to an anion exchange membrane, the blend 
membranes in the present work are not containing any ionizable groups and the conductivity is solely supported by the aqueous electrolyte absorbed into the membrane structure [25]. The data are summarized in Figure 7 as indicated by the solid symbols, clearly showing that the ion conductivity increased with increasing electrolyte uptake due to the increasing PVP content of the initial polymer blend. For example, in 10 wt.\% aqueous $\mathrm{KOH}$ the ion conductivity of the membranes prepared from the polymer blends containing 30,60 and $90 \mathrm{wt} . \%$ PVP was $8.3 \times 10^{-}$ ${ }^{6}, 7.6 \times 10^{-3}, 3.3 \times 10^{-2} \mathrm{~S} \mathrm{~cm}^{-1}$, respectively. The conductivity of the membranes in $20 \mathrm{wt} . \%$ was in general higher than that recorded for the corresponding membranes in $10 \mathrm{wt} . \% \mathrm{KOH}$ due to the intrinsic conductivity behavior of the absorbed electrolyte [56]. Similarly, in $20 \mathrm{wt} \% \mathrm{KOH}$, the conductivity increased by nearly 4 orders of magnitude as the PVP content of the initial polymer blend increased from 30 to $90 \mathrm{wt} . \%$ and reached a value as high as $0.17 \mathrm{~S} \mathrm{~cm}^{-1}$. At PVP contents below $30 \mathrm{wt} . \%$ in the initial polymer, the ion conductivity was too low to be measured, apparently due to the low electrolyte uptake. For comparison, the conductivity of polybenzimidazole membranes in $20 \mathrm{wt} . \%$ is typically around $0.09 \mathrm{~S} \mathrm{~cm}^{-1}$ at room temperature [21].

In order to assess the stability of the membranes, the conductivity was recorded after aging in $20 \mathrm{wt} . \%$ aqueous $\mathrm{KOH}$ at $60{ }^{\circ} \mathrm{C}$ for one week as shown by the open symbols in Figure 7 . The ion conductivity followed the same trend as observed before aging, and increased with increasing PVP content of the initial polymer blend as a result of the increasing electrolyte content of the membrane structure. The ion conductivity after aging in $10 \mathrm{wt} . \% \mathrm{KOH}$ was nearly unchanged compared to that of the as-prepared membrane. However, after aging in $20 \mathrm{wt} . \% \mathrm{KOH}$ the conductivity of the membranes at PVP contents $>60$ wt.\% was lowered. As shown in Figure S2, the FT-IR spectra of the membranes after aging (and after washing and drying) were nearly identical with the corresponding spectra of the as-prepared membranes. This suggests limited 
compositional changes of the polymer fraction of the membranes. Similarly, the ${ }^{1} \mathrm{H}$ NMR spectra after aging, washing and drying of the membranes with PVP contents of $0-60 \mathrm{wt} . \%$ in the initial polymer blend were nearly identical with the spectra of the as-prepared membrane, as shown in Figure S3. The corresponding PVP contents as determined by ${ }^{1} \mathrm{H}$ NMR for the aged membranes are shown in Figure 2c, showing that no significant leaching of the PVP component occurred during the aging test. The membranes with PVP contents of $75 \%$ and $90 \%$ were partly insoluble after the aging test. The partial crosslinking was evidenced by the formation of a gel fraction, which was insoluble in chloroform. The partial crosslinking was possibly triggered by hydrolytic ring opening of the lactam rings in alkaline environment $[57,58]$. Hydrolytic ring opening of the lactam rings in PVP would likely change the appearance of the FT-IR spectrum in the carbonylstretching region, which was not observed, and the degree of crosslinking should therefore be relatively low.

The standard deviation of the measured conductivity calculated from the multiple impedance scans recorded for the same sample did not exceed the size of the data points. However, repeated measurements on different samples would likely introduce more significant deviation, particularly for the samples at high PVP contents. This is due to the small difference between $R$ and $R_{\text {blank }}$ (Equation 6), which implies that small variations in measured resistance for $R$ translate to large variations in the calculated conductivity. 


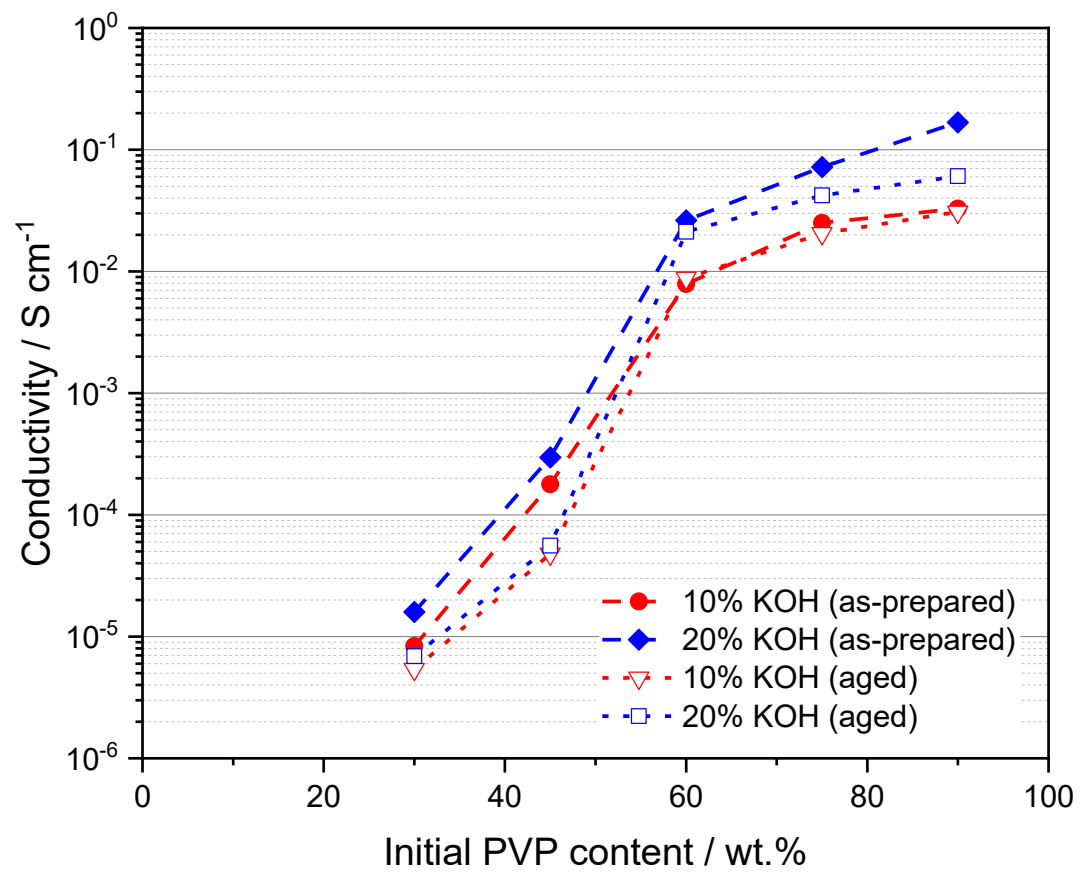

Figure 7 Room temperature ionic conductivity in 10 and $20 \mathrm{wt} . \%$ aqueous $\mathrm{KOH}$ of the membranes prepared from the polymer blends containing 30-90 wt.\% PVP.

\subsection{Water electrolysis testing}

To assess the practical feasibility of the membranes as separators in alkaline water electrolyzers, the membrane composition with 75\% PVP was down-selected for cell tests. This composition exhibited the best compromise between mechanical robustness and ionic conductivity among the evaluated compositions. Membranes were cast to thicknesses of approximately 50, 120, 180 and $240 \mu \mathrm{m}$ (undoped, wet-state), which upon doping resulted in membrane thicknesses of 50, 115, 210 and $255 \mu \mathrm{m}$. The $50 \mu \mathrm{m}$ membrane showed minor defects originating from the casting and was prone to short-circuiting during assembly, possibly caused by slight gasket-electrode overlap, and was hence excluded from the presented data. 
During the test, the cells were kept at $500 \mathrm{~mA} \mathrm{~cm}{ }^{-2}$ at $60{ }^{\circ} \mathrm{C}$ in $20 \mathrm{wt} . \% \mathrm{KOH}$ for 7 days, representing conditions slightly milder than conventional electrolyzers, which normally operate near $80{ }^{\circ} \mathrm{C}$ and at $25-35 \mathrm{wt} . \% \mathrm{KOH}$. The steady state polarization behavior at the beginning of the test and at the end (after 7 days) are shown in Figures $8 \mathrm{a}$ and 8b, respectively. Data recorded using a Zirfon diaphragm and a $m$-PBI membrane are also shown for comparison. Interestingly, the cells based on the PSU-PVP blend membranes showed comparable performance regardless of their thickness. This suggests that the membrane contribution to the total cell resistance is minor, and variation towards high current density are likely also associated with variations in the volume of entrapped gas within the electrodes and variances in electrode performance. Although gas entrapment is mostly an electrode effect, the hydrophilicity of the separator may play a role. Below $200 \mathrm{~mA} \mathrm{~cm}^{-2}$ (see Figure S4), the behavior shows the expected trend, with a higher cell voltage for the thicker membranes. The cells equipped with PSU-PVP membranes exhibit somewhat larger cell resistance, as indicated by the slope of the polarization curve, than the cell with $m$-PBI, but substantially lower resistance than the Zirfon based cell. We note that the Zirfon cell experienced an increase in resistance between the initial and final measurements likely cause by some degree of pore blocking. Either by gas entrapment or nucleation inside the diaphragm or by particulate contamination predominantly on the anode side, which likely takes place while recording the initial polarization curve when current densities exceed $200 \mathrm{~mA} \mathrm{~cm}{ }^{-2}$. This phenomenon was only observed for the Zirfon based cell and manifested as continuously increasing voltage (not reaching steady state value) at the different setpoints of the initial polarization curve (Figure S5). Furthermore, visual inspection upon disassembly of all the cell tests revealed contamination of the separator at the anode side, likely due to insufficient stability of the Ni-Fe anodes used in the present study. The polymer membranes are likely less susceptible to contamination by particulate 
matter than the porous diaphragm due to their homogeneous nature without distinct pores, and will not experience blocking of surface or internal pores by accumulating gas.

(a)

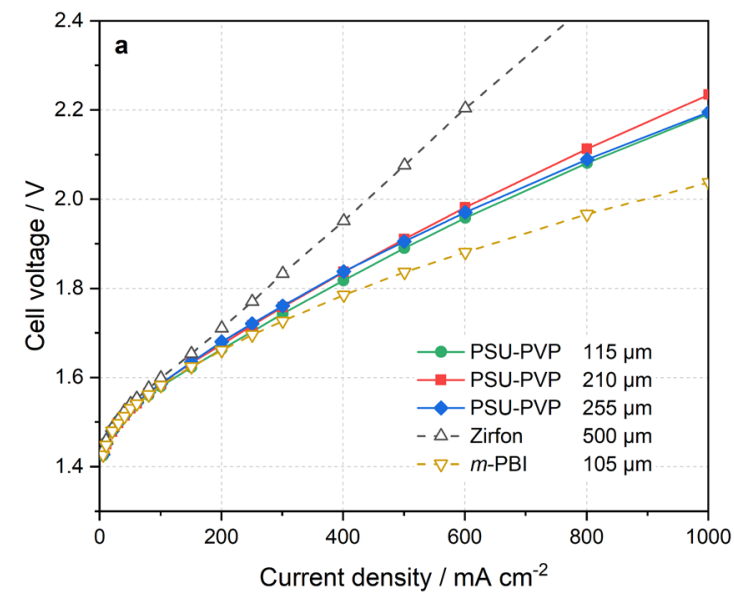

(c)

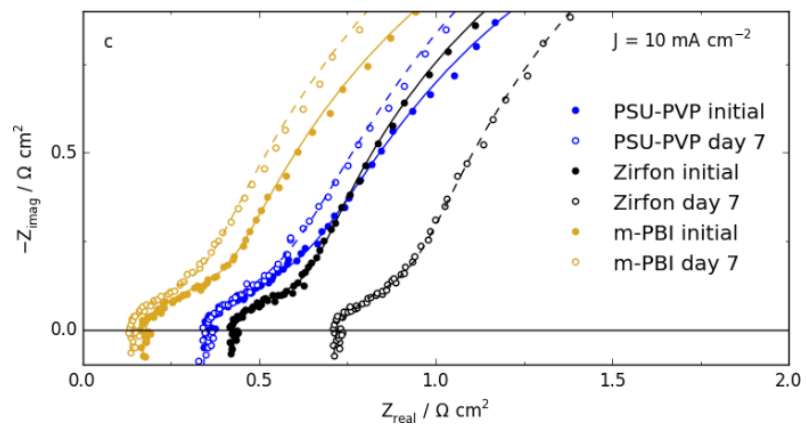

(b)

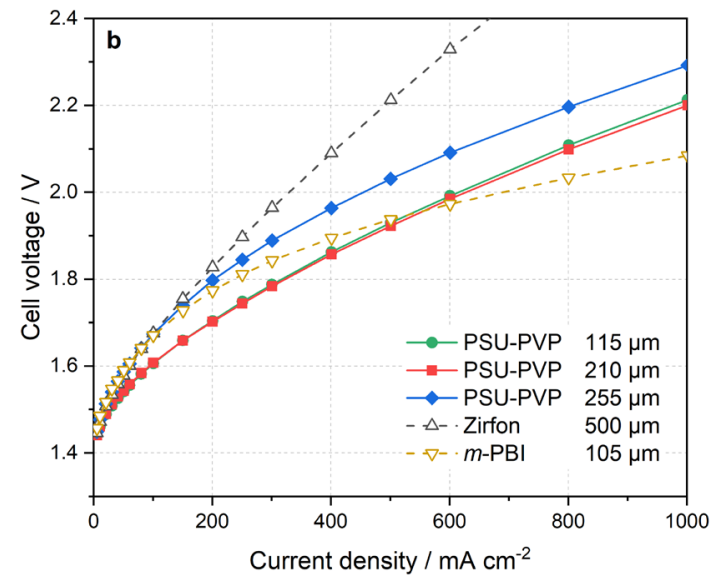

(d)

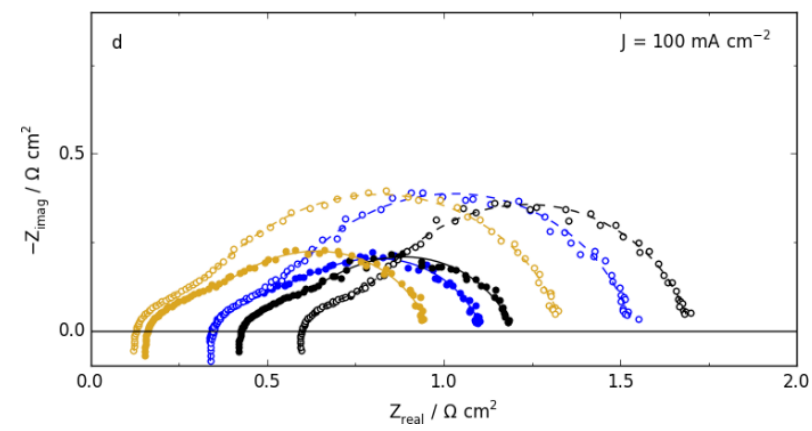

(e)

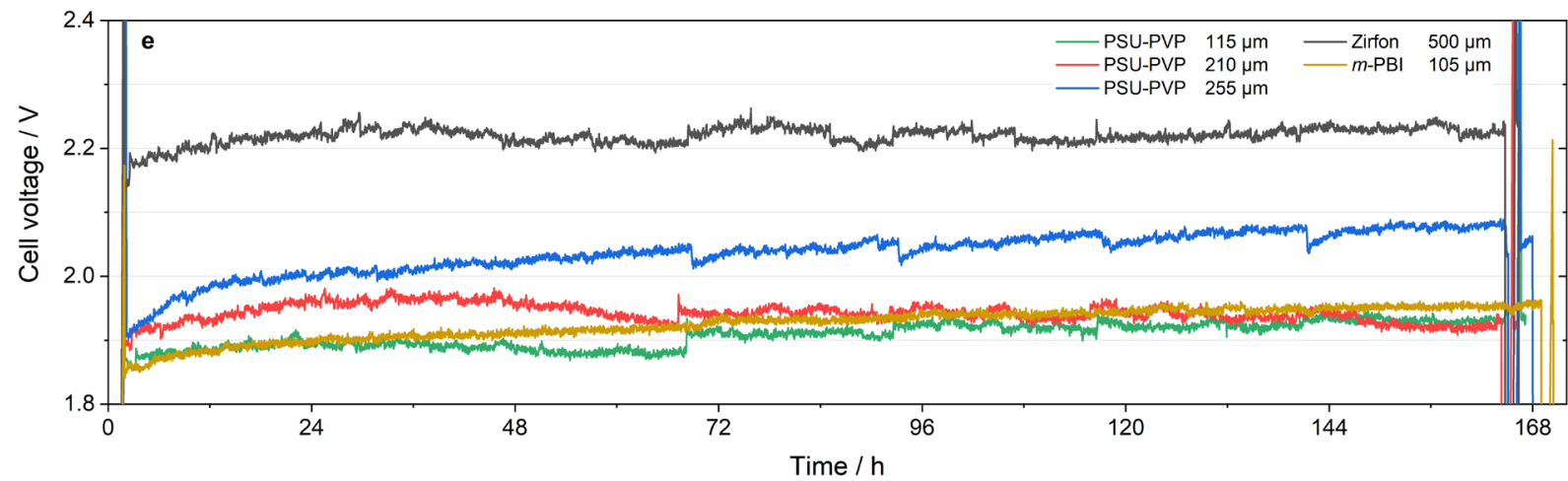


Figure 8 Steady state polarization curves recorded after break-in (a) and after 165-170 h (b) at $500 \mathrm{~mA} \mathrm{~cm}{ }^{-2}$ in 20 wt. $\%$ aqueous $\mathrm{KOH}$ at $60^{\circ} \mathrm{C}$. Nyquist plots of EIS measurements recorded prior to initial and final polarization at $10 \mathrm{~mA} \mathrm{~cm}^{-2}$ (c) and at $100 \mathrm{~mA} \mathrm{~cm}^{-2}$ (d) for selected cells. The shown PSU-PVP data is based on a $255 \mu \mathrm{m}$ membrane. Points represent measured data, and lines represent a fit based on an L-R-RQ-RQ equivalent circuit fit. Time evolution of the cell voltage (e).

From the polarization curves at the end of the test (Figure 8b) it is clear that the electrode stability varied between the cell tests, as seen by a substantial difference in the activation region. The electrode degradation was supported by EIS measurements recorded at $10 \mathrm{~mA} \mathrm{~cm} \mathrm{~cm}^{-2}$ (Figure $8 \mathrm{c}$ ) and $100 \mathrm{~mA} \mathrm{~cm}^{-2}$ (Figure $8 \mathrm{~d}$ ), which show an increase in total cell impedance from the initial to the final (day 7) measurement. The time evolution of the cell voltage during the one week of operation at $500 \mathrm{~mA} \mathrm{~cm}^{-2}$ is shown in Figure 8e. All cells exhibit the largest degree of deactivation during the initial $24 \mathrm{~h}$, after which the cell voltage predominantly stabilize within a voltage window with fluctuations of varying irregular behavior. The notable jumps in cell voltage during steady state operation seen for most of the cell tests are associated with resupplying water to the circulating electrolyte, affecting both temperature and concentration gradients temporarily.

EIS was employed to separate the ohmic resistances from the electrode polarization resistances. The Nyquist plots in Figure 8c and 8d compare the thickest PSU-PVP membrane $(\sim 255 \mu \mathrm{m})$ with the reference Zirfon and $m$-PBI membranes. The initial area specific series resistance as estimated by equivalent circuit fitting of the $100 \mathrm{~mA} \mathrm{~cm}^{-2}$ measurements, are for the cell based on the PSU-PVP blend membrane $328 \mathrm{~m} \Omega \mathrm{cm}^{2}$ and for the $m$-PBI membrane $147 \mathrm{~m} \Omega$ $\mathrm{cm}^{2}$. Assuming that the membrane is the sole contributor, this correspond to ionic conductivities 
of about 78 and $71 \mathrm{mS} \mathrm{cm}^{-1}$, which are in good agreement with the ex-situ conductivity data in Figure 7 and as reported previously for $m$-PBI [21]. On the other hand, the Zirfon based cell shows a larger series resistance contribution in comparison to the PSU-PVP and $m$-PBI based cells, as well as a large difference between the first $\left(412 \mathrm{~m} \Omega \mathrm{cm}^{2}\right)$ and last EIS $\left(588 \mathrm{~m} \Omega \mathrm{cm}^{2}\right)$ measurement, further supporting that physical pore blocking occurred during the test as discussed above. Notably, both resistances measured are larger than that given by the specification sheet of Zirfon under similar conditions $\left(<300 \mathrm{~m} \Omega \mathrm{cm}^{2}\right.$ [59]). We suspect that effects from current constrictions and non-ionic ohmic losses are significant, and that we thus overestimate the area specific resistance of all the membranes to some extent. Perhaps more interestingly, the internal resistance of the cell based on $m$-PBI decreased during the stability test, which likely is a consequence of membrane thinning due to degradation $[21,26]$. However, the area specific series resistance of the cell based on the PSU-PVP blend membranes remained nearly unchanged during the tests, confirming good stability of the membrane under the applied experimental conditions on the investigated timescale.

After 7 days of electrolysis operation at $500 \mathrm{~mA} \mathrm{~cm}^{-2}$ at $60{ }^{\circ} \mathrm{C}$ in $20 \mathrm{wt} . \% \mathrm{KOH}$, the cells were turned off and disassembled. The PSU-PVP appeared visually intact and could be completely dissolved in DMSO- $d_{6}$ after washing in water and drying. The ${ }^{1} \mathrm{H}$ NMR spectra of the used membranes (Figure S6) showed no apparent signs of degradation, apart from a signal at $1.26 \mathrm{ppm}$ which may originate from hydrolyzed PVP. The PVP content after the electrolysis tests as estimated from the integrated ${ }^{1} \mathrm{H}$ NMR spectra was 32, 49 and 55 wt.\%, for the membranes with thicknesses of 115, 210 and $255 \mu \mathrm{m}$, respectively. This indicate that gradual leaching of PVP appear to take place but is limited to the near surface region of the membranes, as indicated by the 
larger relative degree of leaching for the thinner membranes. Nonetheless, it suggests that covalent anchoring of the hydrophilic component is a rational strategy to prevent leaching.

In order to assess the membrane system under more challenging operating conditions, the temperature was increased to $80{ }^{\circ} \mathrm{C}$ for a single test with a $120 \mu \mathrm{m}$ membrane. The test duration was extended to more than $700 \mathrm{~h}$. As indicated by the polarization data shown in Figure 9a, the cell performance remained stable during the test duration. However, as shown in Figure 9b, the cell voltage at a $500 \mathrm{~mA} \mathrm{~cm}$-2 fluctuated between 1.9-2.1 V during the test period due to concentration changes of the electrolyte. While water was supplied to the electrolyte periodically to compensate for the water consumption from the electrochemical processes, evaporative losses of water were not accounted for and resulted in dryout of the cell after $760 \mathrm{~h}$ and membrane failure. This was likely due to the dramatic concentration increase of $\mathrm{KOH}$ and embrittlement of the membrane (see discussion in connection to Figure 4). The results suggest that electrolyte management is critical to ensure longevity of the membranes and that further improvements towards improving robustness is still desired. 

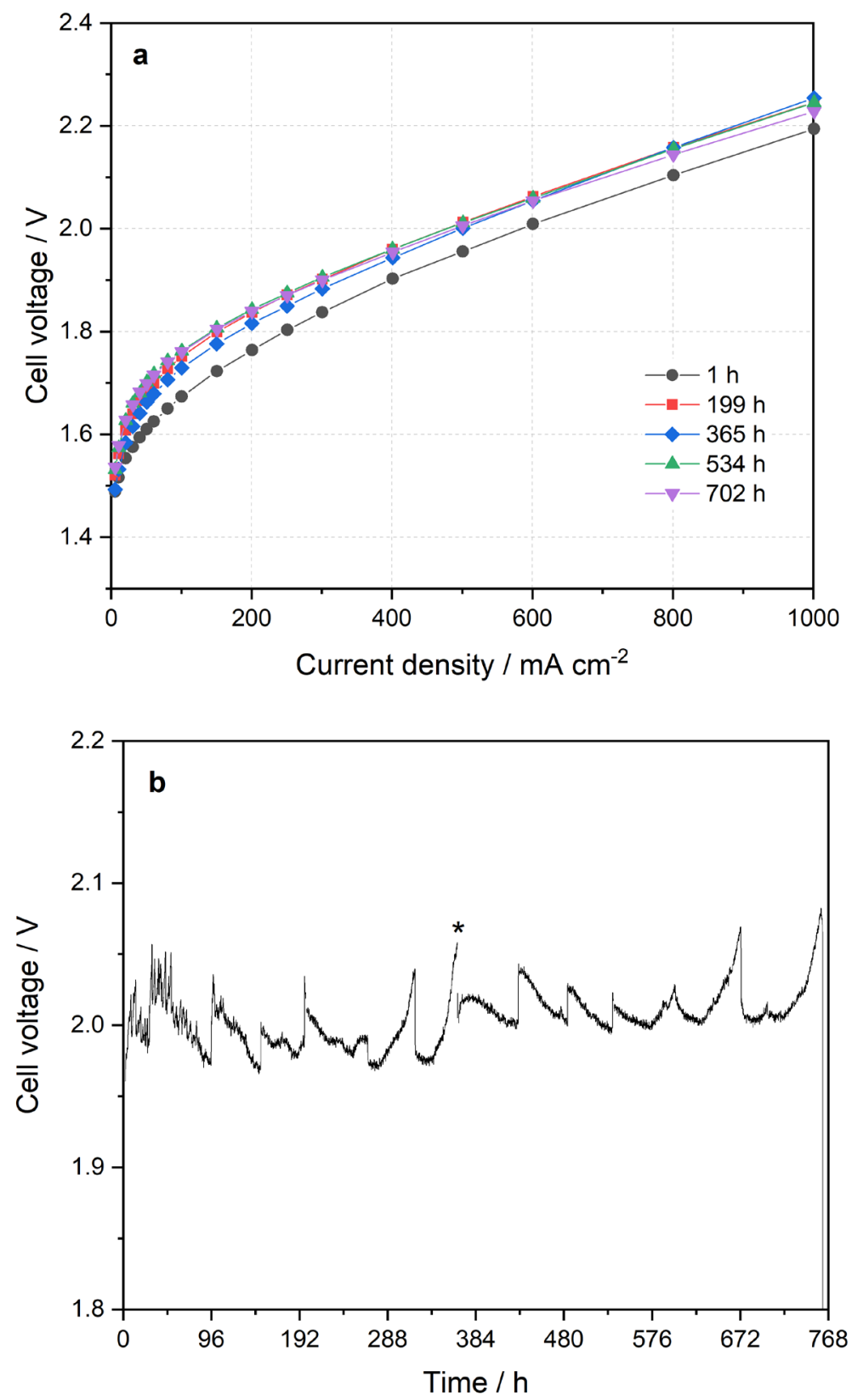

Figure 9 Cell test using a $120 \mu \mathrm{m}$ PSU-PVP membrane with a proprietary cathode and a nickel foam anode operated at $500 \mathrm{~mA} \mathrm{~cm}{ }^{-2}$, at $80{ }^{\circ} \mathrm{C}$ with a liquid electrolyte initial concentration of 20 wt.\% KOH. Evolution in polarization curves (a) and durability profile (b). Gradual evaporation losses resulted in increasing electrolyte concentration approaching saturation concentration. The liquid electrolyte was replaced once during the experiment after approximately $365 \mathrm{~h}$ marked by the asterisk. 


\section{Conclusions}

Co-casting of polysulfone (PSU) and poly(vinylpyrrolidone) (PVP) from dimethylacetamide gives visually homogeneous and transparent polymer blend membranes throughout the whole composition range. The water uptake increases with increasing PVP content of the membrane and result in significant swelling at PVP contents higher than $45 \mathrm{wt} . \%$. Despite its high solubility in water, the major fraction of PVP is effectively immobilized and remains in the membrane after work-up in water, and even after aging in $20 \mathrm{wt} . \% \mathrm{KOH}$ at $60{ }^{\circ} \mathrm{C}$ for one week. The swollen membranes with initial PVP contents above $45 \mathrm{wt} . \%$ support ion conductivity in technologically relevant range (10-100 $\left.\mathrm{mS} \mathrm{cm}^{-1}\right)$ after equilibration in 10-20 wt.\% aqueous $\mathrm{KOH}$, while sufficient mechanical robustness for handling and processing is maintained. Replacing the conventional state-of-the-art separator with the PSU-PVP blend membrane system, containing 75 wt.\% PVP, reduced the cell voltage by several hundred millivolts when operated at intermediate current densities of 500-1000 $\mathrm{mA} \mathrm{cm}^{-2}$. The performance of the membrane was stable for at least one week of operation $500 \mathrm{~mA} \mathrm{~cm}{ }^{-2}$ in $20 \mathrm{wt} . \% \mathrm{KOH}$ at $60{ }^{\circ} \mathrm{C}$. At $80{ }^{\circ} \mathrm{C}$, the cell performance was stable for $>700 \mathrm{~h}$, but evaporative losses of water resulted in a gradually increasing $\mathrm{KOH}$ concentration of the electrolyte and ultimately and enhanced membrane degradation.

\section{Acknowledgement}

This work was financially supported by DTU Energy and the Danish Energy Agency via the EUDP program (Project: Boosting economic electricity storage (BEEST), no. EUDP17-1: 12542) (BEEST). Solvay Specialty Polymers is gratefully acknowledged for providing the PSU used in this work. 


\section{References}

[1] B. Pivovar, N. Rustagi, S. Satyapal, Hydrogen at scale ( $\mathrm{H}_{2} @$ Scale) Key to a clean, economic, and sustainable energy system, Electrochem. Soc. Interface 27 (2018) 47-52.

[2] D. Pletcher, X. Li, Prospects for alkaline zero gap water electrolysers for hydrogen production, Int. J. Hydrogen Energy 36 (2011) 15089-15104.

[3] M. Carmo, D.L. Fritz, J. Mergel, D. Stolten, A comprehensive review on PEM water electrolysis, Int. J. Hydrogen Energy 38 (2013) 4901-4934.

[4] U. Babic, M. Suermann, F.N. Büchi, L. Gubler, T.J. Schmidt, Identifying critical gaps for polymer electrolyte water electrolysis development, J. Electrochem. Soc. 164 (2017) F387-F399. [5] M. Schalenbach, G. Tjarks, M. Carmo, W. Lueke, M. Mueller, D. Stolten, Acidic or alkaline? Towards a new perspective on the efficiency of water electrolysis, J. Electrochem. Soc. 163 (2016) F3197-F3208.

[6] Y.J. Leng, G. Chen, A.J. Mendoza, T.B. Tighe, M.A. Hickner, C.Y. Wang, Solid-state water electrolysis with an alkaline membrane, J. Am. Chem. Soc. 134 (2012) 9054-9057.

[7] L. Xiao, S. Zhang, J. Pan, C. Yang, M. He, L. Zhuang, J. Lu, First implementation of alkaline polymer electrolyte water electrolysis working only with pure water, Energy Environ. Sci. 5 (2012) 7869-7871.

[8] Y.-C. Cao, X. Wu, K. Scott, A quaternary ammonium grafted poly vinyl benzyl chloride membrane for alkaline anion exchange membrane water electrolysers with no-noble-metal catalysts, Int. J. Hydrogen Energy 37 (2012) 9524-9528. 
[9] X. Wu, K. Scott, A polymethacrylate-based quaternary ammonium $\mathrm{OH}^{-}$ionomer binder for non-precious metal alkaline anion exchange membrane water electrolysers, J. Power Sources 214 (2012) 124-129.

[10] E.J. Park, C.B. Capuano, K.E. Ayers, C. Bae, Chemically durable polymer electrolytes for solid-state alkaline water electrolysis, J. Power Sources 375 (2018) 367-372.

[11] X.H. Li, F.C. Walsh, D. Pletcher, Nickel based electrocatalysts for oxygen evolution in high current density, alkaline water electrolysers, Phys. Chem. Chem. Phys. 13 (2011) 1162-1167.

[12] A.G. Wright, J. Fan, B. Britton, T. Weissbach, H.-F. Lee, E.A. Kitching, T.J. Peckham, S. Holdcroft, Hexamethyl-p-terphenyl poly(benzimidazolium): A universal hydroxide-conducting polymer for energy conversion devices, Energy Environ. Sci. 9 (2016) 2130-2142.

[13] J. Hnát, M. Plevová, J. Žitka, M. Paidar, K. Bouzek, Anion-selective materials with 1,4diazabicyclo[2.2.2] octane functional groups for advanced alkaline water electrolysis, Electrochim. Acta 248 (2017) 547-555.

[14] Z.C. Liu, S.D. Sajjad, Y. Gao, H.Z. Yang, J.J. Kaczur, R.I. Masel, The effect of membrane on an alkaline water electrolyzer, Int. J. Hydrogen Energy 42 (2017) 29661-29665.

[15] J.R. Varcoe, P. Atanassov, D.R. Dekel, A.M. Herring, M.A. Hickner, P.A. Kohl, A.R. Kucernak, W.E. Mustain, K. Nijmeijer, K. Scott, T.W. Xu, L. Zhuang, Anion-exchange membranes in electrochemical energy systems, Energy Environ. Sci. 7 (2014) 3135-3191.

[16] G. Merle, M. Wessling, K. Nijmeijer, Anion exchange membranes for alkaline fuel cells: A review, J. Membr. Sci. 377 (2011) 1-35.

[17] B. Xing, O. Savadogo, Hydrogen/oxygen polymer electrolyte membrane fuel cells (PEMFCs) based on alkaline-doped polybenzimidazole (PBI), Electrochem. Commun. 2 (2000) 697-702. 
[18] D. Aili, K. Jankova, J. Han, N.J. Bjerrum, J.O. Jensen, Q. Li, Understanding ternary poly(potassium benzimidazolide)-based polymer electrolytes, Polymer 84 (2016) 304-310.

[19] L. Zeng, T.S. Zhao, L. An, G. Zhao, X.H. Yan, Physicochemical properties of alkaline doped polybenzimidazole membranes for anion exchange membrane fuel cells, J. Membr. Sci. 493 (2015) 340-348.

[20] D. Aili, M.K. Hansen, R.F. Renzaho, Q. Li, E. Christensen, J.O. Jensen, N.J. Bjerrum, Heterogeneous anion conducting membranes based on linear and crosslinked $\mathrm{KOH}$ doped polybenzimidazole for alkaline water electrolysis, J. Membr. Sci. 447 (2013) 424-432.

[21] M.R. Kraglund, D. Aili, K. Jankova, E. Christensen, Q. Li, J.O. Jensen, Zero-gap alkaline water electrolysis using ion-solvating polymer electrolyte membranes at reduced $\mathrm{KOH}$ concentrations, J. Electrochem. Soc. 163 (2016) F3125-F3131.

[22] L.A. Diaz, J. Hnát, N. Heredia, M.M. Bruno, F.A. Viva, M. Paidar, H.R. Corti, K. Bouzek, G.C. Abuin, Alkali doped poly (2,5-benzimidazole) membrane for alkaline water electrolysis: Characterization and performance, J. Power Sources 312 (2016) 128-136.

[23] D. Aili, A.G. Wright, M.R. Kraglund, K. Jankova, S. Holdcroft, J.O. Jensen, Towards a stable ion-solvating polymer electrolyte for advanced alkaline water electrolysis, J. Mater. Chem. A 5 (2017) 5055-5066.

[24] L.A. Diaz, R.E. Coppola, G.C. Abuin, R. Escudero-Cid, D. Herranz, P. Ocón, Alkali-doped polyvinyl alcohol - Polybenzimidazole membranes for alkaline water electrolysis, J. Membr. Sci. 535 (2017) 45-55.

[25] M.K. Kraglund, M. Carmo, G. Schiller, S.A. Ansar, D. Aili, E. Christensen, J.O. Jensen, Ionsolvating membranes as a new approach towards high-rate alkaline electrolyzers, Energy. Environ. Sci. 12 (2019), 3313-3318. 
[26] D. Aili, K. Jankova, Q. Li, N.J. Bjerrum, J.O. Jensen, The stability of poly(2,2'-(mphenylene)-5,5'-bibenzimidazole) membranes in aqueous potassium hydroxide, J. Membr. Sci. 492 (2015) 422-429.

[27] O.D. Thomas, K.J.W.Y. Soo, T.J. Peckham, M.P. Kulkarni, S. Holdcroft, Anion conducting poly(dialkyl benzimidazolium) salts, Polym. Chem. 2 (2011) 1641-1643.

[28] D. Henkensmeier, H.R. Cho, H.J. Kim, C.N. Kirchner, J. Leppin, A. Dyck, J.H. Jang, E. Cho, S.W. Nam, T.H. Lim, Polybenzimidazolium hydroxides - Structure, stability and degradation, Polym. Degrad. Stab. 97 (2012) 264-272.

[29] O.D. Thomas, K. Soo, T.J. Peckham, M.P. Kulkarni, S. Holdcroft, A stable hydroxideconducting polymer, J. Am. Chem. Soc. 134 (2012) 10753-10756.

[30] A.G. Wright, S. Holdcroft, Hydroxide-stable ionenes, ACS Macro Lett. 3 (2014) 444-447.

[31] T. Weissbach, A.G. Wright, T.J. Peckham, A. Sadeghi Alavijeh, V. Pan, E. Kjeang, S. Holdcroft, Simultaneous, synergistic control of ion exchange capacity and cross-linking of sterically-protected poly(benzimidazolium)s, Chem. Mater. 28 (2016) 8060-8070.

[32] D. Henkensmeier, H. Cho, M. Brela, A. Michalak, A. Dyck, W. Germer, N.M.H. Duong, J.H. Jang, H.-J. Kim, N.-S. Woo, T.-H. Lim, Anion conducting polymers based on ether linked polybenzimidazole (PBI-OO), Int. J. Hydrogen Energy 39 (2014) 2842-2853.

[33] P. Vermeiren, J.P. Moreels, A. Claes, H. Beckers, Electrode diaphragm electrode assembly for alkaline water electrolysers, Int. J. Hydrogen Energy 34 (2009) 9305-9315.

[34] D. Burnat, M. Schlupp, A. Wichser, B. Lothenbach, M. Gorbar, A. Zuttel, U.F. Vogt, Composite membranes for alkaline electrolysis based on polysulfone and mineral fillers, J. Power Sources 291 (2015) 163-172. 
[35] J. Pan, C. Chen, L. Zhuang, J. Lu, Designing advanced alkaline polymer electrolytes for fuel cell applications, Acc. Chem. Res. 45 (2012) 473-481.

[36] C.G. Arges, V. Ramani, Two-dimensional NMR spectroscopy reveals cation-triggered backbone degradation in polysulfone-based anion exchange membranes, Proc. Natl. Acad. Sci. U.S.A. 110 (2013) 2490-2495.

[37] A.D. Mohanty, S.E. Tignor, J.A. Krause, Y.-K. Choe, C. Bae, Systematic alkaline stability study of polymer backbones for anion exchange membrane applications, Macromolecules 49 (2016) 3361-3372.

[38] M. Hayama, K. Yamamoto, F. Kohori, T. Uesaka, Y. Ueno, H. Sugaya, I. Itagaki, K. Sakai, Nanoscopic behavior of polyvinylpyrrolidone particles on polysulfone/polyvinylpyrrolidone film, Biomaterials 25 (2004) 1019-1028.

[39] M. Hulko, M. Kunz, M. Yildirim, S. Homeyer, O. Amon, B. Krause, Cell-free plasma hemoglobin removal by dialyzers with various permeability profiles, Sci Rep 5 (2015) 9 .

[40] X. Xu, H.N. Wang, S.F. Lu, Z.B. Guo, S.Y. Rao, R.J. Xiu, Y. Xiang, A novel phosphoric acid doped poly(ethersulphone)-poly(vinyl pyrrolidone) blend membrane for high-temperature proton exchange membrane fuel cells, J. Power Sources 286 (2015) 458-463.

[41] J. Zhang, J. Liu, S. Lu, H. Zhu, D. Aili, R. De Marco, Y. Xiang, M. Forsyth, Q. Li, S.P. Jiang, Ion-exchange-induced selective etching for the synthesis of amino-functionalized hollow mesoporous silica for elevated-high-temperature fuel cells, ACS Appl. Mater. Interfaces 9 (2017) 31922-31930.

[42] X. Ren, H. Li, K. Liu, H. Lu, J. Yang, R. He, Preparation and investigation of reinforced PVP blend membranes for high temperature polymer electrolyte membranes, Fibers Polym. 19 (2018) 2449-2457. 
[43] C.X. Wu, S.F. Lu, H.N. Wang, X. Xu, S.K. Peng, Q.L. Tan, Y. Xiang, A novel polysulfonepolyvinylpyrrolidone membrane with superior proton-to-vanadium ion selectivity for vanadium redox flow batteries, J. Mater. Chem. A 4 (2016) 1174-1179.

[44] L. Zeng, T.S. Zhao, L. Wei, Y.K. Zeng, Z.H. Zhang, Polyvinylpyrrolidone-based semiinterpenetrating polymer networks as highly selective and chemically stable membranes for all vanadium redox flow batteries, J. Power Sources 327 (2016) 374-383.

[45] J. Kerres, G. Eigenberger, S. Reichle, V. Schramm, K. Hetzel, W. Schnurnberger, I. Seybold, Advanced alkaline electrolysis with porous polymeric diaphragms, Desalination 104 (1996) 4757.

[46] S. Lu, L. Zhuang, J. Lu, Homogeneous blend membrane made from poly(ether sulphone) and poly(vinylpyrrolidone) and its application to water electrolysis, J. Membr. Sci. 300 (2007) 205210.

[47] Section 5: Concentrative Properties of Aqueous Solutions: Density, Refractive Index, Freezing Point Depression, and Viscosity, in: W.M. Haynes (Ed.) CRC Handbook of Chemistry and Physics, CRC Press/Taylor and Francis Boca Raton, FL, $93^{\text {rd }}$ Edition (Internet Version 2013). [48] A. Kirkebæk, D. Aili, B. Yue, A. Vassiliev, L.N. Cleemann, J.O. Jensen, Q. Li, Fuel cell electrolytes of polybenzimidazole membranes cross-linked with bis(chloromethyl) arenes, Fuel Cells 18 (2018), 688-697.

[49] Z. Lu, W.W. Xu, W. Zhu, Q. Yang, X.D. Lei, J.F. Liu, Y.P. Li, X.M. Sun, X. Duan, Threedimensional NiFe layered double hydroxide film for high-efficiency oxygen evolution reaction, Chem. Commun. 50 (2014) 6479-6482. 
[50] J. Zhang, T. Wang, P. Liu, Z.Q. Liao, S.H. Liu, X.D. Zhuang, M.W. Chen, E. Zschech, X.L. Feng, Efficient hydrogen production on $\mathrm{MoNi}_{4}$ electrocatalysts with fast water dissociation kinetics, Nat. Commun. 8 (2017) 8.

[51] P. Haug, M. Koj, T. Turek, Influence of process conditions on gas purity in alkaline water electrolysis, Int. J. Hydrogen Energy 42 (2017) 9406-9418.

[52] C. Wu, J. Zhang, S. Lu, Y. Xiang, S.P. Jiang, Acid pretreatment to enhance proton transport of a polysulfone-polyvinylpyrrolidone membrane for application in vanadium redox flow batteries, ChemPlusChem, 83 (2018) 909-914.

[53] R. Bhattacharya, T.N. Phaniraj, D. Shailaja, Polysulfone and polyvinyl pyrrolidone blend membranes with reverse phase morphology as controlled release systems: Experimental and theoretical studies, J. Membr. Sci. 227 (2003) 23-37.

[54] D. Aili, M.K. Hansen, J.W. Andreasen, J. Zhang, J.O. Jensen, N.J. Bjerrum, Q. Li, Porous poly(perfluorosulfonic acid) membranes for alkaline water electrolysis, J. Membr. Sci. 493 (2015) 589-598.

[55] Q. Li, R.H. He, J.O. Jensen, N.J. Bjerrum, PBI-based polymer membranes for high temperature fuel cells - Preparation, characterization and fuel cell demonstarion, Fuel Cells 4 (2004) 147-159.

[56] R.J. Gilliam, J.W. Graydon, D.W. Kirk, S.J. Thorpe, A review of specific conductivities of potassium hydroxide solutions for various concentrations and temperatures, Int. J. Hydrogen Energy 32 (2007) 359-364.

[57] M.I. Vinnik, Y.V. Moiseyev, Mechanism of hydrolysis of lactams in aqueous solutions of potassium hydroxide, Tetrahedron 19 (1963) 1441-1454. 
[58] C.C. Anderson, F. Rodriguez, D.A. Thurston, Crosslinking aqueous poly(vinylpyrrolidone) solutions by persulfate, J. Appl. Polym. Sci. 23 (1979) 2453-2462.

[59] Zirfon Perl ${ }^{\mathrm{TM}}$, Product specification sheet, AGFA. 